EDUR • Educação em Revista. 2021; 37:e25000

DOI: http://dx.doi.org/10.1590/0102-469825000

(1) (1) https://creativecommons.org/licenses/by/4.0/

ARTIGO

\title{
UMA PROPOSTA PARA A ELABORAÇÃO DO JOGO PEDAGÓGICO A PARTIR DA CONCEPÇÃO DE ESQUEMAS CONCEITUAIS
}

\author{
FERNANDO APARECIDO DE MORAES ${ }^{1}$ \\ ORCID: https://orcid.org/0000-0002-8714-6533 \\ MÁRLON HERBERT FLORA BARBOSA SOARES ${ }^{2}$ \\ ORCID: https://orcid.org/0000-0002-3273-8603
}

\begin{abstract}
RESUMO: Este artigo teórico objetiva apresentar uma proposta de como o jogo pedagógico deve ser analisado e compreendido a partir da concepção de esquemas conceituais. Para tanto, os autores discutem sobre a concepção de jogos recreativos a partir da ótica de três esquemas conceituais, os esquemas: Regras, Interação Lúdica e Cultura. Posteriormente, após caracterizar o jogo pedagógico, de acordo com discussão realizada sob a luz da literatura específica, os autores apresentam e discutem em detalhes o esquema primário proposto por eles para se pensar o jogo pedagógico, o esquema Educação Formal. Por fim, apontam os autores que a proposta pode ser utilizada para se pensar e elaborar jogos pedagógicos não somente para o ensino das Ciências Naturais praticado na Educação Básica, mas em qualquer disciplina vinculada à Educação Formal.
\end{abstract}

Palavras-chave: Jogo Pedagógico, Lúdico, Educação Formal, Esquemas Conceituais

\section{A PROPOSAL FOR THE ELABORATION OF A PEDAGOGICAL GAME FROM THE FORMULATION OF CONCEPTUAL SCHEMES}

\begin{abstract}
This theoretical study aimed to present a proposal of how the pedagogical game should be analyzed and understood from the conception of conceptual schemes. To this end, the authors discuss the design of recreational games from the perspective of three conceptual schemes, namely: Rules, Playful Interaction and Culture. Subsequently, after characterizing the pedagogical game, according to a discussion conducted in the light of specific literature, the authors present and discuss in detail the primary scheme proposed by them to think about the pedagogical game, the Formal Education arrangement. Finally, they point out that the proposal can be used to think and develop pedagogical games not only for teaching Natural Sciences practiced in Basic Education, but in any subject linked to Formal Education.
\end{abstract}

Keywords: Pedagogical Game, Playful, Formal Education, Conceptual Schemes

\footnotetext{
${ }^{1}$ Universidade Federal de Jataí (UFJ). Jataí, GO, Brasil. < fernandoaparecido@ufj.edu.br>

${ }^{2}$ Universidade Federal de Goiás (UFG). Goiânia, GO, Brasil. <marlon@ufg.br>

Educação em Revista|Belo Horizonte|v.37|e25000|2021
} 


\section{UNA PROPUESTA PARA LA ELABORACIÓN DE JUEGO PEDAGÓGICO A PARTIR DE LA CONCEPCIÓN DE ESQUEMAS CONCEPTUALES}

RESUMEN: Este artículo, de carácter teórico, objetiva presentar una propuesta de como el juego pedagógico debe ser analizado y comprendido a partir de la concepción de esquemas conceptuales. Para tanto, los autores discuten a respecto de la concepción de juegos recreativos desde la óptica de tres esquemas conceptuales: Reglas, Interacción Lúdica y Cultura. Posteriormente, después de caracterizar el juego pedagógico y de acuerdo con discusión realizada a la luz de la literatura específica, los autores presentan y discuten en detalles un esquema primario para pensar el juego pedagógico: el esquema denominado Educación Formal. Por último señalan que la propuesta puede ser utilizada para pensar y elaborar juegos pedagógicos no solamente para la enseñanza de las Ciencias de la Naturaleza en la Educación Básica, sino en cualquier asignatura de la Educación Formal.

Palabras clave: Juego Pedagógico, Lúdico, Educación Formal, Esquemas Conceptuales

\section{INTRODUÇÃO}

Este artigo apresenta uma proposta desenvolvida em tese de doutorado defendida recentemente, que buscou investigar as possibilidades de construção de conhecimento a partir da elaboração de um jogo pedagógico, sob a luz da concepção de esquemas conceituais e da teoria de Jean Piaget (1896-1980), para trabalhar com conceitos evolutivos no ensino de Biologia do Ensino Médio. Em específico, abordaremos aspectos teóricos da elaboração do jogo pedagógico a partir da concepção de quatro esquemas conceituais, três deles propostos por Salen e Zimmerman (2004), e o outro, proposto por nós.

O artigo se estrutura em tópicos que abordarão, inicialmente, o que entendemos por jogo pedagógico. Posteriormente, discutiremos a concepção dos esquemas conceituais primários para se pensar em um jogo na perspectiva dos esquemas primários propostos por Salen e Zimmerman (2004), quais sejam, os esquemas: Regras, Interação Lúdica e Cultura. A partir da discussão deste referencial, faremos a proposição de um novo esquema, chamando de esquema primário Educação Formal, na tentativa de se pensar a criação de um jogo pedagógico.

A discussão teórica estabelecida no texto se dá pela aproximação que buscamos realizar entre Salen e Zimmerman (2004) e os autores clássicos do campo do jogo, no sentido stricto, como Brougère (1998), Huizinga (2012) e Caillois (2017). Por fim, o estudo aponta para as possibilidades de utilização do jogo pedagógico como uma das estratégias pedagógicas para o processo de ensino e aprendizagem, tanto no ensino das Ciências Naturais, quanto para outras áreas disciplinares da Educação Formal.

\section{O JOGO PEDAGÓGICO}

Em algum momento da história o jogo assume perspectivas de ensinar algo, ou mais acuradamente, algum conteúdo escolar. A partir de então, ele passa a receber adjetivações específicas, como jogo didático, jogo educativo e jogo pedagógico. Mas o que o torna um jogo educativo, didático ou pedagógico? Há alguma diferença entre eles?

Com base em discussão recente realizada por Cleophas, Cavalcanti e Soares (2018), abordaremos alguns aspectos a respeito das diferentes concepções que envolvem o jogo em uma perspectiva educacional, buscando caracterizar a concepção de jogo pedagógico que estamos abordando no artigo. Mas, antes disso, voltaremos um pouco no tempo para situarmos o jogo educativo em um contexto histórico.

Há de destacar-se que no século XVI houve um grande acontecimento que impulsionou o interesse pelos jogos educativos: o aparecimento da Companhia de Jesus. Segundo Soares (2004, p. 36), "Ignácio de Loyola, militar e nobre, compreende a importância dos jogos de exercícios para a formação do ser humano e preconiza sua utilização como recurso auxiliar do ensino". 
Kishimoto (2011, p. 32) nos aponta que no Renascimento o jogo assume um importante papel educativo, pois "ao atender necessidades infantis, o jogo infantil torna-se forma adequada para a aprendizagem dos conteúdos escolares. Assim, para se contrapor aos processos verbalistas de ensino, à palmatória vigente, o pedagogo deveria dar forma lúdica aos conteúdos".

No século XVIII, sob forte influência do desenvolvimento da ciência positivista, houve o aumento e a diversificação dos jogos em diferentes áreas, inclusive a das Ciências Naturais, sob o propósito de se ensinar ciências à realeza e à aristocracia (SOARES, 2004). A partir dessa época, o jogo ganha espaço nas salas de aulas chancelado, principalmente, pela Matemática que o utiliza e passa a manifestar-se em sua defesa para o desenvolvimento do raciocínio lógico.

Nos séculos que seguem, o jogo se torna cada vez mais objeto de interesse das áreas relacionadas ao desenvolvimento e a aprendizagem do indivíduo. Autores como Piaget (1896-1980) e Lev Vygotsky (1896-1934) atribuem importante significado ao jogo no processo de aprendizagem. Ainda que de modo diferente, ambos são responsáveis por dar um lugar de destaque ao jogo no processo de desenvolvimento do sujeito e construção da aprendizagem. Muito do que se discute hoje sobre os jogos educativos é fundamentado no conhecimento apresentado por estes dois importantes autores.

Soares (2013, p. 45) destaca que "certamente, desde muito tempo, relaciona-se o jogo com a aprendizagem, porém, predomina sempre a ideia de que o jogo se presta mais à recreação do que ao ensino, em contraposição ao trabalho escolar". Considerando essa afirmação, defendemos que é preciso superar a concepção de que o jogo em sala de aula está sendo utilizado apenas para facilitar a vida do professor, passando o tempo da aula, ou servindo de uma ferramenta auxiliar quando ele deixa de planejar a aula.

Deste modo, é preciso superar, também, o que Brougère (1998) chama de "paradoxo do jogo educativo", no qual seria inconcebível pensar em uma atividade lúdica voluntária associada à seriedade impositiva que o processo de ensino e aprendizagem demanda. A literatura específica tem nos apresentado resultados significativos das inúmeras possibilidades que o jogo traz para a sala de aula, inclusive no processo de ensino e aprendizagem das Ciências Naturais (GALVÃO et al., 2012; MIRANDA, 2015; ANJOS; GUIMARÃES, 2018; LOCATELLI, 2018).

Rezende et al. (2019, p. 257), sobre as vantagens do jogo educativo no ensino de Química, apontam que

O desenvolvimento do jogo educativo possibilitou verificar o quanto o lúdico é importante nos processos de ensino e aprendizagem, e que esta metodologia contribui para a aprendizagem dos alunos, colocando-os em uma posição de protagonismo da construção de seu próprio conhecimento $[\ldots]$.

No XI Encontro Nacional de Pesquisa em Educação em Ciências, Duarte et al. (2017) apresentaram o trabalho intitulado "Roleta da Evolução: uma ferramenta didática para o ensino de Biologia no Ensino Médio". Os autores concluem o trabalho afirmando que "[...] é possível sugerir que este modelo tem eficácia no processo de ensino aprendizagem, se utilizado de forma correta pelo professor" (DUARTE et al., 2017, p. 9).

Araújo e Santos (2018, p. 82), sobre a utilização do jogo educativo para o ensino de Física, ressaltam que "[...] a utilização de jogos pedagógicos, facilitam a compreensão dos conteúdos, além de promover a interação e participação dos estudantes na atividade proposta. Tais recursos estimulam, potencialmente, cognição, afeição, socialização, motivação e a criatividade".

No sentido de avançar na discussão teórica sobre os jogos educativos, Cleophas, Cavalcanti e Soares (2018) discutem, à luz de referências do campo teórico do jogo, a qualidade educativa atribuída ao jogo, considerando que ele, em seu sentido stricto, é voluntário e livre e não pode ser uma atividade imposta, pois, aí deixaria de ser jogo, como apontam Brougère (2002), Huizinga (2012) e Caillois (2017). A partir da discussão realizada por eles, Cleophas, Cavalcanti e Soares (2018) defendem a ideia de que o jogo educativo pode ser aceito sem a preocupação de que, por ser educativo, deixaria de ser jogo, no "paradoxo do jogo educativo".

A partir de então, Cleophas, Cavalcanti e Soares (2018) apresentam dois tipos de jogos educativos, sendo o primeiro deles, o jogo educativo informal, que seria aquele que ensina de maneira despretensiosa, ou seja, não foi pensado para um propósito formal de ensino e é utilizado, inicialmente, 
com finalidade meramente lúdica. De outro modo, nos apresentam o jogo educativo formalizado, que se organizará em duas subcategorias: o jogo didático e o jogo pedagógico. Para eles, o jogo educativo formalizado é aquele que, diferentemente do informal, tem alguma relação direta com a educação formal, seja no aspecto de sua construção, ou no aspecto referente à proposta de utilização educativa dele.

Ao definirem as diferenças entre o jogo didático e o jogo pedagógico, os autores nos apresentam as características peculiares para cada um. A principal diferenciação que fazem entre os dois tipos de jogos se encontra no processo de elaboração do jogo e em relação aos objetivos de utilização. Para eles, o jogo didático surge a partir da adaptação de um jogo já existente, além disso, os conteúdos escolares são propostos, em geral, para um reforço ou uma avaliação diagnóstica. Em relação ao jogo pedagógico, os autores destacam a necessidade do ineditismo, ou seja, o seu design é pensado e elaborado especificamente para desenvolver habilidades cognitivas, podendo ser utilizado em diferentes momentos no contexto escolar, como para ensinar algum conteúdo (CLEOPHAS; CAVALCANTI; SOARES, 2018).

Deste modo, definem o jogo pedagógico como:

Jogo Educativo Formalizado que não foi adaptado de nenhum outro jogo, ou seja, seria um jogo contendo elevado grau de ineditismo, visando desenvolver habilidades cognitivas sobre conteúdos específicos. Esse tipo de jogo mantém, em sua essência, o papel instrucional, atuando, assim, como uma estratégia de ensino que foi cautelosamente planejada para estimular a capacidade de autorreflexão intencional nos alunos, levando-os a uma mudança de comportamento em relação à sua aprendizagem, sem perder o aspecto prazeroso que uma atividade lúdica possui (CLEOPHAS; CAVALCANTI; SOARES, 2018, p. 39).

É importante destacar que, para além dessa conceituação estabelecida por Cleophas, Cavalcanti e Soares (2018), existem outras classificações adotadas por outros autores, como Kishimoto (2011) e Chateau (1987). Para alguns deles, as terminologias "pedagógico", "didático" e "educativo" se equivalem. Outros, consideram completamente diferentes, como no caso de Cunha (2012), em relação ao jogo educativo e jogo didático. Para a autora, o jogo educativo envolveria diversos tipos de ações na esfera corporal, cognitiva, afetiva e social do estudante. Já o jogo didático seria uma atividade regrada e mais específica, relacionada ao ensino de conceitos e/ou conteúdos.

A respeito dessa discussão conceitual, Messeder-Neto (2016, p. 179) afirma que sendo "educativo" ou "didático", o que importa é que "no caso de o jogo ir à sala de aula, ele sempre terá que possuir conteúdo e ou conceitos, caso contrário não deveria estar nesta instituição". Afirma, ainda, que "independentemente de chamar de jogo educativo ou jogo didático, o que o professor precisa atentar é se o conteúdo está presente e se ele ocupa um lugar central do jogo" (MESSEDER-NETO, 2016, p. 180).

Diante das divergências conceituais apresentadas, o nosso pensamento coaduna com as ideias de Cleophas, Cavalcanti e Soares (2018), no que se refere à conceituação dos jogos educativos, didáticos e pedagógicos. Daí vem o nosso entendimento de jogo pedagógico utilizado no presente trabalho, pensando que é preciso aprofundarmos na discussão teórica do jogo educativo formalizado, até para evitarmos certas assimilações deformantes, frutos de confusões entre os termos "didático", "pedagógico" e "educativo", que levam a erros conceituais no que se refere à elaboração, avaliação e utilização dos jogos em sala de aula.

Desse modo, ao considerarmos o conceito de jogo pedagógico apresentado pelos autores, sentimos a necessidade de ampliarmos a discussão a respeito das características a serem contempladas neste tipo de jogo, de "elevado grau de ineditismo" e "visando desenvolver habilidades cognitivas sobre conteúdos específicos". Por isso, apresentamos a proposta que considera as características de um jogo pedagógico a partir da concepção dos esquemas conceituais.

\section{A CONCEPÇÃO DO JOGO PEDAGÓGICO A PARTIR DOS ESQUEMAS CONCEITUAIS PRIMÁRIOS}

Os esquemas primários de Salen e Zimmerman 
Considerando que há uma extensa literatura discutindo o jogo no sentido stricto, como em Chateau (1987), Brougère (1998), Huizinga (2012), Soares (2013) e Caillois (2017), neste trabalho apresentamos uma discussão teórica dos esquemas conceituais primários de Salen e Zimmerman (2004), estabelecendo uma relação dialógica com o que a literatura específica do campo do jogo aponta.

Salen e Zimmerman (2004) entendem o jogo recreativo a partir daquilo que chamam de esquemas primários. Com um texto que dialoga com referenciais importantes do campo teórico do jogo, optam por considerar o jogo como a um sistema. Nas palavras dos próprios autores "um jogo é um sistema no qual os jogadores se envolvem em um conflito artificial, definido por regras, que implica um resultado quantificável" (SALEN; ZIMMERMAN, 2012a, p. 95).

Detalhando este conceito, os autores nos apontam que, primeiramente, considerando um sistema como um conjunto de partes que juntas formam um todo complexo e, organicamente diferente das partes individuais, o jogo deve ser considerado como a um sistema. Os jogadores são definidos como os participantes que interagem com o sistema, experimentando a interação lúdica do jogo. Ao interagirem com o sistema, os jogadores vivem situações conflitantes, sejam elas representadas por momentos de competição ou cooperação. Essas experiências são normatizadas pelas regras, que impõem o que os jogadores podem ou não fazer. Como resultado de tudo isso, podemos verificar que algum objetivo foi atingido, podendo ser a vitória ou outro objetivo qualquer que o jogo apresente e seja passível de verificação (SALEN; ZIMMERMAN, 2012a).

No que se refere à concepção e análise de um jogo, os autores nos apresentam a ideia teórica que muito nos interessou, que seria trabalhar sob a ótica de esquemas conceituais primários, definidos por eles da seguinte forma: "um esquema é uma forma de sistematizar e organizar conhecimento. Um esquema de design de jogos é uma forma de entender jogos, uma lente conceitual que podemos aplicar à análise ou criação de um jogo" (SALEN; ZIMMERMAN, 2012a, p. 23, grifo dos autores).

Para propor essa ideia de esquemas primários, um dos autores utilizados por eles como referencial teórico foi Piaget. Para Piaget $(1980 ; 1987)$ os esquemas são entendidos como estruturas cognitivas necessárias para que o indivíduo acomode as informações assimiladas. No início da vida, os sujeitos apresentam esquemas primordiais que vão se transformando e dando origem a outros esquemas. Quanto mais assimilação e acomodação acontecer, mais haverá mudanças nos esquemas préconstituídos, ou serão originados novos esquemas. Piaget afirma que os esquemas vão se tornando cada vez mais complexos e nos permitem compreender os objetos, bem como as suas interrelações no mundo em que nos inserimos.

Os esquemas primários podem ser entendidos, a partir do pensamento de Salen e Zimmerman (2012a), como uma estrutura conceitual que organiza alguns aspectos particulares de um sistema, de um jogo. Ao se dar atenção em especial para um esquema, as demais estruturas conceituais ficam em um segundo plano, ainda que saibamos que elas se interrelacionam com ele. Ao compreendermos melhor como se constitui cada esquema primário, podemos entender melhor como o jogo se constitui num sistema projetado para a interação lúdica.

Sob esse modelo de conceber um jogo, os autores propõem, então, três esquemas primários, sendo eles: as Regras, a Interação Lúdica e a Cultura. Para eles:

\footnotetext{
Esses esquemas não só organizam formas de olhar jogos, mas também quando considerados como um todo, oferecem um método geral para o estudo do design de jogos. Cada esquema traz à tona certos aspectos dos jogos, ao basear-se em esquemas anteriores para chegar a um entendimento polivalente de jogos (SALEN; ZIMMERMAN, 2012a, p. 23).
}

Desse modo, nos tópicos que seguem iremos discutir, resumidamente, sobre os três esquemas apresentados por Salen e Zimmerman (2004).

\section{Esquema primário - Regras}

As regras em um jogo são as responsáveis por nos inserir e nos manter no universo fictício proposto pelo jogo. São elas que o fazem acontecer, possibilitando as experiências interativas dentro daquilo que Salen e Zimmerman (2004) chamam de "círculo mágico". As regras devem ser seguidas e respeitadas para que o jogo possa atingir os objetivos pretendidos. A este respeito, Huizinga (2012, p. 
14) aponta que "todo jogo tem suas regras. São estas que determinam aquilo que "vale" dentro do mundo temporário por ele circunscrito. As regras de todos os jogos são absolutas e não permitem discussão." Para Soares (2013, p. 40) as regras "[...] implicam em um contrato social de convivência entre os participantes".

Buscando conceituar o jogo, Caillois (2017, p. 19, grifo do autor) destaca a importância das regras ao afirmar que "todo jogo é um sistema de regras que definem o que é ou o que não é do jogo, ou seja, o permitido e o proibido. Estas convenções são ao mesmo tempo arbitrárias, imperativas e inapeláveis".

Tanto Huizinga (2012), quanto Caillois (2017), apresentam a ideia de que o jogo constitui uma "realidade autônoma", que é a capacidade de transportar os jogadores para um outro mundo, fora da realidade cotidiana à qual pertencem os jogadores. Para entendermos isso melhor, sugerimos que cada um pense em suas próprias experiências com jogos. Ao assim fazermos, é possível perceber que quando estamos jogando um jogo que consegue nos envolver no seu "círculo mágico", passamos várias horas, até mesmo dias, sem nos preocuparmos com o que está a nossa volta, ou seja, com a vida real. Mergulhamos em outra dimensão de nossa vida, aquela em que podemos assumir diferentes papeis, sem responsabilidades, sobretudo, sem pensarmos em nossas preocupações da vida cotidiana.

A respeito desta magia que o jogo nos apresenta, Salen e Zimmermam (2004) elaboram a ideia do "círculo mágico", brevemente citado por Huizinga (2012) na obra Homo Ludens. Para os autores, o "círculo mágico" trata de um lugar especial criado pelo jogo, "[...] é onde o jogo acontece. Jogar um jogo significa entrar em um círculo mágico ou, talvez, criar um quando o jogo começa.", concluindo que “o termo ‘círculo mágico’ é adequado porque há, de fato, algo verdadeiramente mágico que acontece quando o jogo começa” (SALEN; ZIMMERMAN, 2012a, p. 111).

Curiosamente, Soares (2013, p. 108), ao discutir sobre os jogos de tabuleiro, nos informa que:

[...] os jogos de tabuleiro são representações simbólicas da Mandala, termo sânscrito que significa "círculo mágico". Suas formas circulares, ou mesmo quadrangulares, devem insinuar a presença de um centro em torno do qual se organizam, expressando a ideia de totalidade, de algo perfeito, fechado em si mesmo.

Tal característica coloca o jogo em uma situação diferente da vida cotidiana, pois, ao contrário dela, o jogo sempre acontece em um tempo histórico determinado, tendo início e término. O espaço é relativizado no jogo, podendo acontecer em um nível de ambiente virtual imaginativo, como os jogos de interpretações ou simulações de papéis, como o Roling Playing Game (RPG). Caillois (2017), ao buscar apontar as características do jogo, destaca que ele é uma atividade circunscrita em limites e espaços próprios, incerta e dotada de uma realidade fictícia, o que, também, vai ao encontro da ideia de "círculo mágico". Com essas considerações, Huizinga (2012, p. 24) nos alerta que "o jogo tem, por natureza, um ambiente instável. A qualquer momento é possível a 'vida quotidiana' reafirmar seus direitos [...]".

Sendo assim, considerando o "círculo mágico" como algo instável, Sallen e Zimmerman (2004) nos apresentam que as regras são as responsáveis pela sua manutenção, ou seja, sem elas o círculo se rompe, rompendo-se pode ser o fim de um jogo, pois as pessoas podem perder o interesse por ele. A partir dessa relação direta das regras com o "círculo mágico", entendemos que elas operacionalizam uma maneira de os jogadores interagirem com o sistema, criando o "círculo mágico" e tornando possível que as experiências vivenciadas aconteçam dentro do espaço de possibilidades que o jogo apresenta, ainda que saibamos que na concepção de um jogo não conseguiremos prever todas as experiências possíveis de interação.

Diante do exposto, apresentamos as principais características que Sallen e Zimmerman (2012b) elencam a respeito das regras. Para eles, as regras limitam a ação do jogador (regulam as ações); são explícitas e inequívocas (completas e sem ambiguidade); são compartilhadas por todos os jogadores (unanimidade); são fixas (não mudam quando um jogo é jogado); são obrigatórias (inquestionáveis); e repetíveis (se mantêm entre uma partida e outra).

Sobre tais características, discordamos somente da afirmação de que as regras são fixas, pois entendemos que isso irá depender do tipo de regra de que estamos falando. No texto dos próprios autores 
encontramos uma tipificação das regras que nos demonstram que algumas delas, como as implícitas, não são fixas e dependem da interação entre os jogadores.

Salen e Zimmerman (2012b) nos apresentam a existência de três tipos de regras: as operacionais (aquelas que são apresentadas no início do jogo e buscam orientar o comportamento dos jogadores, permitindo que o jogo se inicie e se desenvolva); as constitutivas (aquelas subjacentes que estão "sob a superfície" das regras operacionais, que aparecem ao longo do jogo); e as implícitas (aquelas regras "não escritas", que dizem respeito a situações que podem ou não acontecer no jogo, a depender da maneira como os jogadores estão interagindo com o sistema). Neste caso, sobre as regras implícitas não podemos afirmar que são fixas, pois elas dependerão das atitudes dos jogadores em relação ao jogo.

Kishimoto $(2011$, p. 27) também discute sobre diferentes tipos de regras em um jogo e nos apresenta que "há regras explícitas, como no xadrez ou amarelinha, regras implícitas como na brincadeira de faz de conta, em que a menina se faz passar pela mãe que cuida da filha. São regras internas, ocultas, que ordenam e conduzem a brincadeira." Soares (2013, p. 42) coaduna parcialmente com a autora ao falar das regras explícitas e implícitas, afirmando que "as regras explícitas são as próprias regras declaradas e consensuais de um jogo, as implícitas são as habilidades mínimas necessárias para que se possa praticar um jogo em que há regras explícitas".

Em geral, os teóricos do campo do jogo que nos apresentam as regras como uma das principais características de um jogo, são extremamente favoráveis ao cumprimento delas. No entanto, sabem que em algum momento do jogo elas podem ser quebradas. A esse respeito Sallen e Zimmerman (2012b, p. 27) afirmam que "é claro que a autoridade das regras nem sempre é rigorosamente obedecida: a trapaça acontece". Para Caillois (2017) a partir do momento que o jogo estabelece uma tênue fronteira entre o real e o fictício, a contaminação do jogo com elementos da vida real pode corromper facilmente a natureza do jogo.

Para discutir melhor sobre o comportamento dos jogadores em relação às regras, Sallen e Zimmerman (2012b) nos apresentam alguns tipos comuns de jogadores, sendo: o jogador padrão (respeita as regras e a sua autoridade no jogo), o dedicado (além de apresentar as características do jogador padrão, ele estuda todas as possibilidades do jogo, explorando melhores estratégias para conseguir a vitória), o antiesportivo (segue as regras, mas não se importa com os outros), o trapaceiro (quebra as regras para tentar conseguir a vitória) e o desmancha-prazeres (quase sem características de um jogador, não se envolve no círculo-mágico e pode acabar com uma partida).

Em geral, os dois primeiros tipos de jogadores prevalecem entre os inúmeros tipos de jogos que estão disponíveis para serem jogados. No entanto, para pensar a criação de um jogo é importante considerar as existências dos demais tipos, pois todos podem coexistir em um jogo, o que irá alterar a dinâmica do sistema interativo estabelecido pelas regras, podendo até mesmo colocá-lo em risco, como é o caso do desmancha-prazeres.

Sobre o trapaceiro, Caillois (2017, p. 89) destaca que "[...] ele permanece no universo do jogo. Quando contorna as regras, pelo menos o faz fingindo respeitá-las. Procura vender gato por lebre. É desonesto e hipócrita." O trapaceiro é aquele jogador que se utiliza de estratégias diversas e não aceita as regras para atingir o objetivo final do jogo, por exemplo, aquele jogador de baralho que esconde uma carta curinga para utilizá-la no momento certo e ganhar a partida.

Conforme apresentamos, como esquema primário Salen e Zimmerman (2004) organizam o esquema Regras levando em consideração o escopo conceitual que nos apresentam como necessário para entendermos melhor o esquema. Deste modo, discutem a natureza das regras, os tipos de regras e a relação delas com o sistema projetado, aí envolvendo várias questões, como os conflitos e as incertezas que se manifestam no espaço de possibilidades do "círculo mágico". Além disso, os autores destacam a possibilidade de os jogadores quebrarem as regras, o que nos leva a pensar em outras possibilidades dentro do sistema.

Diante do exposto, afirmamos que as regras de um jogo nos permitem entender o sistema que foi ou está sendo projetado. Regras, enquanto um esquema primário de organização conceitual, organiza um escopo de conhecimentos que se associam em busca da construção e manutenção do "círculo mágico" de um jogo. Defendemos, pois, que a partir das regras o sistema começa a funcionar, não se restringindo somente a este momento inicial, porque elas também serão responsáveis pela manutenção da interação lúdica que se dará nas experiências interativas. A interação lúdica em um jogo 
só será permitida a partir do momento em que os jogadores forem seduzidos a entrar no "círculo mágico" do jogo, ou seja, no tempo-espaço fictício que o jogo apresenta. No entanto, a permanência no jogo será garantida pelas interações que, por sua vez, serão normatizadas por intermédio das regras.

\section{Esquema primário - Interação Lúdica}

Interagir vem da palavra interação, ação entre dois objetos ou pessoas, ou ainda entre pessoas e objetos (HOUAISS, 2009). Em nossa concepção de interação voltada ao jogo, destacamos que, além da importante interação existente entre as pessoas, os jogadores, há a interação das pessoas com o sistema que foi projetado para isso, ou seja, o jogo, como também, das pessoas com o conhecimento presente no jogo.

O termo "lúdico", de acordo com o Dicionário Eletrônico Houaiss de Língua Portuguesa (HOUAISS, 2009), ora está associado diretamente ao jogo, ora ao comportamento infantil ou ao sentimento de prazer. Além disso, também é associado ao comportamento observado em fases de desenvolvimento do ser humano, de acordo com a Psicologia e a Psicopedagogia. De fato, podemos observar isso em importantes teóricos, como em Piaget (1978) e Chateau (1987). Para Piaget (1978), é por meio das atividades lúdicas que a criança se satisfaz e alimenta a (re)construção dos esquemas. Não foi à toa que Huizinga (2012) nos trouxe a ideia do Homo Ludens. Para ele, o espírito lúdico é algo natural ao ser humano, fazendo parte de sua constituição enquanto ser social.

Para esclarecer melhor sobre essa relação complexa entre o lúdico e o jogo, Salen e Zimmerman (2012c) defendem o jogo como um tipo de atividade lúdica, aquela que promove interações lúdicas. No entanto, consideram que o jogo não é o único responsável por tais interações, uma vez que elas podem ser verificadas em outras atividades e comportamentos humanos, através do ser lúdico. No jogo, a interação acontece por meio das experiências vivenciadas no sistema projetado. A este respeito, Salen e Zimmerman (2012c, p. 36, grifo dos autores) afirmam que:

Interagir com um jogo é experienciar o jogo: ver, tocar, ouvir, cheirar e provar o jogo; mover o corpo durante o jogo, sentir emoções sobre o resultado do jogo em andamento, comunicar-se com outros jogadores, alterar os padrões normais de pensamento. Ao contrário das formas matemáticas claras das regras, a interação lúdica experiencial de um jogo é difusa, obscura e confusa. Mas, é nesse âmbito que os jogadores realmente participam de um jogo, entrando na interação lúdica significativa.

É a partir desse pensamento que os autores destacam a importância do esquema primário Interação Lúdica, pois seria ele o responsável por organizar um escopo conceitual, permitindo a um criador de jogos pensar em todo o espaço de possibilidades de promover experiências significativas para os jogadores. Eles destacam que isso é um dos maiores desafios, pois, "[...] significa considerar as microdimensões e as macrodimensões, desde as pequenas interações momento a momento que confrontam um jogador, até a forma como essas interações básicas se combinam para formar uma trajetória maior da experiência” (SALEN; ZIMMERMAN, 2012c, p. 38).

Para termos um bom jogo, não basta criar o "círculo mágico", é preciso que a magia possibilitada por ele seja capaz de seduzir e conquistar os jogadores para que eles queiram permanecer dentro do universo fictício do jogo. Afinal, a partir do momento que consideramos o jogo como uma atividade voluntária, as pessoas jogam porque querem. Para isso, as experiências interativas devem contemplar o prazer. O prazer, derivado das inúmeras sensações físicas, emocionais, psicológicas ou ideológicas, sempre será uma experiência profunda no jogo, como destacam Salen e Zimmerman (2012c). É aquela sensação que "em qualquer momento em um jogo, um jogador é jogado em várias direções ao mesmo tempo, experimentando uma mistura complexa de prazeres" (SALEN; ZIMMERMAN, 2012c, p. 70).

Sobre este aspecto Soares (2013, p. 25) destaca que "dizer que um jogo não é prazeroso, é dizer que ele não é mais lúdico, é concluir que ele perde o caráter de jogo.” Para o autor, a ludicidade é intrínseca ao jogo e a concepção contrária precisa ser superada, pois há questões epistemológicas de mais urgência no campo teórico dos jogos a serem discutidas. No entanto, ainda encontramos em muitos trabalhos científicos, apresentados em congressos e eventos nacionais da área de Ensino de Ciências, 
títulos que apresentam o termo jogo lúdico, demonstrando que a confusão ainda não foi superada. O jogo é lúdico, ou seja, traz intrinsecamente a característica de diversão e prazer aos jogadores.

No entanto, é importante destacar que alguns autores, como Kishimoto (2011), apontam que, em alguns casos, o desprazer é o elemento que caracteriza determinado tipo específico de jogo. Sobre este aspecto Salen e Zimmerman (2012c) discutem que sensações contrárias ao prazer, como o tédio e a ansiedade, são "armadilhas" possíveis de serem observadas em um jogo mal projetado, ou seja, não são situações intrínsecas ao jogo. Considerar a possibilidade de inexistência do prazer em um jogo nos faz pensar sobre a necessidade de atenção quando o sistema está sendo projetado, para que o prazer possa surgir e permanecer ao longo das experiências vivenciadas. Como muito bem aponta Salen e Zimmerman (2012c, p. 61) "Pensar nos jogos como sistemas de prazer implica que o designer de jogos é um artesão do desejo, moldando o prazer dos jogadores de um jogo".

Deste modo, considerando o esquema primário Interação Lúdica, é importante destacar que o jogo é um sistema projetado para a interação lúdica. Interação esta que pode acontecer a todo o momento no jogo devendo, portanto, ser carregada de boas sensações, como o prazer. Salen e Zimmerman (2012c) apontam que essas interações são muito importantes, podendo assumir, inclusive, um papel transformador até mesmo fora do "círculo mágico". Os autores ainda observam que "[...] a interação lúdica do jogo representa um fim em si. Jogamos, em certa medida, pela interação lúdica em si" (SALEN; ZIMMERMAN, 2012c, p. 54).

Huizinga (2012), também coaduna com esse pensamento, quando afirma que uma das características importantes do jogo se encontra no seu poder de fascinação e intensidade, que não podem ser explicados apenas por análises biológicas. Para ele "[...] é nessa intensidade, nessa fascinação, nessa capacidade de excitar que reside a própria essência e a característica primordial do jogo" (HUIZINGA, 2012, p. 5)

É essa interação que faz com que os jogadores atribuam significados ao que está sendo feito no jogo. Portanto, é importante considerarmos todas as possibilidades interativas ao se projetar o sistema de um jogo. A essência do jogo está nas interações possíveis dentro do "círculo mágico", criado a partir do momento em que o jogo se inicia.

\section{Esquema primário - Cultura}

Há diversos estudos que buscam delimitar o conceito de cultura, demonstrando a polissemia do termo. Neste trabalho adotamos as categorizações de cultura apresentadas por Bodley (1994). Para o autor, o conceito de cultura pode ser sistematizado em algumas categorias, que seguem: tópica, histórica, comportamental, normativa, funcional, mental, estrutural e simbólica. Assim fazendo, o autor relaciona a cultura com diversas características, como as questões tradicionais, o comportamento humano, ideias e valores, um modo de vida, um complexo de ideias e hábitos atribuídos arbitrariamente e compartilhados em determinada sociedade (BODLEY, 1994).

A partir do momento que a cultura é entendida como um termo polissêmico, é importante termos claro quais significados ela assume para que possamos pensar nas inúmeras questões conceituais que poderão se relacionar ao esquema primário Cultura. Uma visão limitada do termo pode nos levar à uma visão reducionista da importância da cultura no processo de elaboração de um jogo, uma vez que ela deve ser levada em consideração antes mesmo do início da concepção do jogo, pois será a partir da cultura que será atribuído o significado a ele.

Um jogo pode ser considerado jogo em uma cultura e não-jogo em outra. Kishimoto (2011, p. 19) aponta que "[...] cada contexto social constrói uma imagem de jogo conforme seus valores e modo de vida, que se expressa por meio da linguagem". Huizinga (2012) nos apresenta que o jogo precede a cultura, uma vez que os animais não esperaram para serem iniciados em práticas culturais para realizarem diversos tipos de jogos. Muitos animais, principalmente quando jovens, realizam várias práticas interativas descritas como jogos. No entanto, o autor destaca que o jogo possui uma função significante que extrapola o simples instinto ou as questões apenas fisiológicas. Essa função significante, que atribui um significado social ao jogo, o torna um importante elemento da cultura.

Assim considerando, é importante pensarmos que os jogos são elaborados agregando-se a eles aspectos da cultura contemporânea, ao mesmo tempo em que se tornam um novo elemento dessa cultura, passando a fazer parte dela. Os jogos são influenciados pela cultura, mas também podem 
influenciá-la, uma vez que são carregados de significados. Sallen e Zimermman (2012d), ao compreenderem a cultura como um elemento constitutivo do próprio jogo e, ao mesmo tempo, entenderem o jogo como a própria cultura, propõem o esquema primário Cultura afirmando que:

Ao contrário dos esquemas em Regras e Interação Lúdica, os esquemas culturais de design de jogos não derivam diretamente das qualidades internas e intrínsecas dos jogos, mas provém da relação entre os jogos e os contextos maiores nos quais são jogados. Esses contextos podem ser ideológicos, práticos, políticos ou até mesmo físicos (SALEN; ZIMMERMAN, 2012d, p. 25).

Os autores nos levam a pensar que ainda que o jogo crie a sua própria realidade dentro do "círculo mágico", ele estará historicamente localizado em um contexto real, como muito bem destacam quando afirmam que "o círculo mágico é um ambiente para o jogo, o espaço no qual as regras assumem um significado especial. Mas o círculo mágico em si existe dentro de um ambiente, a esfera maior da cultura em geral" (SALEN; ZIMMERMAN, 2012d, p. 21).

Para discutirem melhor o esquema primário Cultura, Salen e Zimmerman (2012d) nos apresentam duas formas de entendermos os jogos como cultura, sendo elas: enquanto reflexão e enquanto transformação. Para os autores, há jogos que refletem diretamente a cultura, apresentando elementos diretos que demonstram estar inseridos na respectiva cultura. Outros, possuem a capacidade de transformar a cultura, extrapolando as interações vivenciadas no "círculo mágico". Mas os autores também consideram que, não necessariamente, essas formas são excludentes, podendo ser encontradas em um mesmo jogo.

Sob este ponto de vista, os jogos passam a ser vistos como objetos simbólicos carregados de expressões culturais. Eles podem ser pensados como, inclusive, mecanismos de resistência. Ao pensarmos em jogos que trazem para o seu contexto questões que extrapolam os limites do "círculo mágico", estamos pensando em jogos que possam ser influenciados pela cultura, mas que influenciam principalmente, promovendo transformações em seus aspectos. A esse respeito Salen e Zimmerman (2012d, p. 35) afirmam que "os jogos colocam a cultura 'em jogo', não apenas refletindo a cultura, mas mudando entre as estruturas culturais existentes e dentro dela - por vezes, transformando-as como resultado". Nesse sentido, destacam que os criadores de jogos precisam analisar muito bem quais os significados estão explícitos e implícitos em um jogo.

Outro aspecto destacado por Salen e Zimmerman (2012d, p. 51) sobre as diversas maneiras de vermos o jogo por intermédio do esquema Cultura, é o considerarmos como instrumento ideológico de retórica cultural. Neste caso, os autores nos apontam inúmeras situações que os jogos consideram e reforçam questões, por exemplo, de gênero, políticas, dentre outras. Para eles "as retóricas culturais podem ser um aspecto inconsciente da ideologia de um jogo ou podem ser conscientemente concebidas em um jogo". Estando presentes de forma consciente elas se tornam importantes mecanismos ideológicos, portanto, precisam ser analisadas muito atentamente, para se evitar determinados tipos de situações em que se reproduzam valores e comportamentos sociais nocivos ao bem coletivo de uma sociedade que busca ser democrática.

Ao discutirmos sobre o esquema Cultura, bem como sua importância, pensando em associálo com os outros dois esquemas, Regras e Interação Lúdica, começamos a visualizar a complexidade que é conceber um jogo levando em consideração todos os aspectos dos três esquemas de modo integrado. Buscar a construção de um sistema que como resultado primordial promova a interação lúdica, mas que, além disso, seja historicamente localizado, se torna um enorme desafio a ser enfrentado.

Diante dessas inquietantes considerações a respeito da concepção de um jogo sob a luz dos esquemas primários, à guisa de conclusão deste tópico, apresentamos o conceito de jogo que formulamos a partir do conceito apresentado por Salen e Zimmerman (2004). Entendemos o jogo como sendo: um sistema projetado a partir da associação entre esquemas conceituais primários para promover a interação lúdica em um "círculo mágico", possibilitando experiências diversas. Com este conceito estamos considerando o jogo como um sistema, constituído por diversas partes que interagem como engrenagens de uma máquina. Um sistema projetado, ou seja, planejado detalhadamente. Projetado a partir dos esquemas primários que, necessariamente, não se limitam aos esquemas Regras, Interação Lúdica e Cultura, mas os incluem como condição sine qua non. A partir disso, pensamos que o sistema possibilita diversas interações em espaço/tempo fictícios, promovendo diferentes tipos de experiências. 
Dito isso, nos encaminhamos para o próximo tópico do artigo para apresentarmos o modo como entendemos a concepção de um jogo pedagógico, com um caráter educativo que, neste caso, possibilita experiências de aprendizagem. Esse tipo de jogo que, além de contemplar os esquemas primários propostos por Salen e Zimmerman (2004), na sua concepção necessita de um esquema primário específico para o aspecto educativo. Por sentirmos essa necessidade, propomos o esquema primário Educação Formal, apresentado a partir de agora.

\section{O esquema primário Educação Formal}

Ao nos depararmos com os conceitos de esquemas primários de Salen e Zimmerman (2004), propostos para pensarmos o processo de criação e análise de um jogo recreativo, sentimos a necessidade de construirmos e propormos um quarto esquema. Esquema este que, associado aos outros três, nos permitisse pensar no processo de criação e análise de um jogo pedagógico, considerando a sua peculiaridade no que se refere aos propósitos educativos formalizados.

Planejar, analisar e construir um jogo pedagógico demanda que consideremos, além das Regras, da Interação Lúdica e da Cultura, o esquema conceitual educativo. Demanda, dentre outras questões, levantar os conhecimentos prévios dos estudantes, dominar o conteúdo específico a ser trabalhado no jogo e, sobretudo, ter claro qual teoria de aprendizagem irá embasá-lo para fundamentar as ações pedagógicas. Por isso, considerando estas e outras demandas, as sistematizamos naquilo que estamos chamando de esquema primário Educação Formal, ou seja, uma estrutura conceitual que organiza diversas características importantes, como sub-esquemas conceituais que se interrelacionam para que as possibilidades de existência de um bom jogo pedagógico se materializem.

Sugerimos que este esquema, assim como os demais, seja levado em consideração no processo criativo e avaliativo dos jogos que se enquadrem no grupo dos jogos pedagógicos, seja com propósitos de ensinar conceitos ou reforçar tal processo em um planejamento mais amplo, que envolva diferentes abordagens e métodos pedagógicos. Defendemos que o processo de criação de um jogo pedagógico deva ser pensado a partir dos quatro esquemas primários que, de modo igualitário, se associam: Regras, Interação Lúdica, Cultura e Educação Formal (Figura 1).

Figura 1: Ilustração da interação entre os quatro esquemas primários

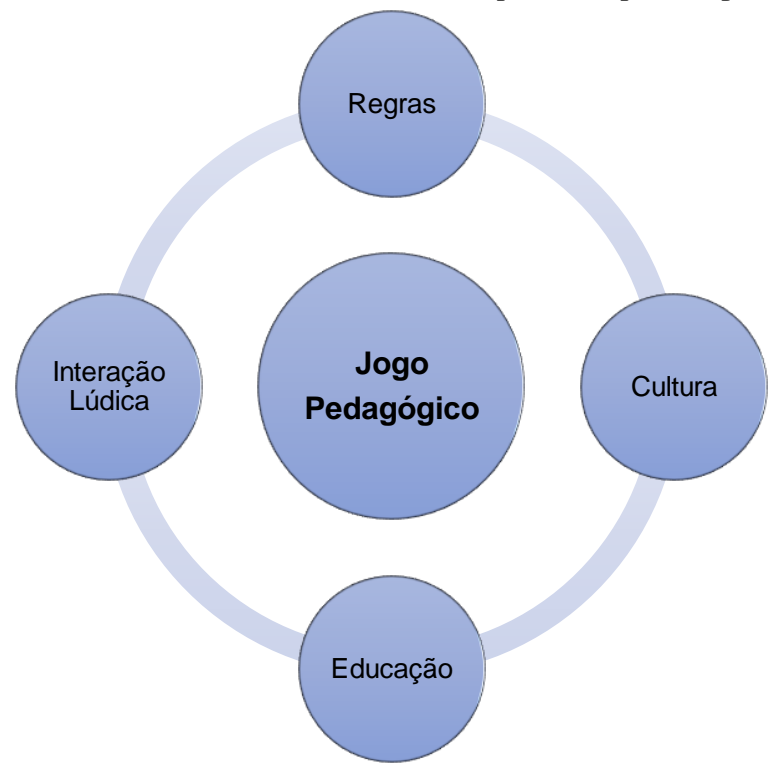

Fonte: elaborado pelos autores.

Antes de entrarmos na discussão a respeito das características do esquema primário Educação Formal, nos propomos a discutir um pouco sobre o termo "educação", uma vez que o esquema se relaciona diretamente a ele. Na LDBEN (BRASIL, 1996) encontramos em seu artigo primeiro, o entendimento de que "a educação abrange os processos formativos que se desenvolvem na vida familiar, na convivência humana, no trabalho, nas instituições de ensino e pesquisa, nos movimentos sociais e organizações da sociedade civil e nas manifestações culturais". Nos apoiando em Piaget (1982), 
pensamos que a educação, de fato, é um processo formativo. Um processo que busca a adaptação do sujeito à sociedade. Que envolve o desenvolvimento e a construção. Que deve promover a constante desequilibração do sujeito, fazendo-o buscar uma nova condição de equilíbrio. Um processo social dialógico que envolve a aprendizagem, que, por sua vez, demanda o ensino e a interação.

A partir do momento em que a escola se propõe a ser um ambiente formal de educação, por meio da convivência e interação entre as pessoas com o conhecimento formalizado, temos que ter bastante cuidado com o processo que nela será desenvolvido. $\mathrm{O}$ caminho a ser seguido para que este processo aconteça deve estar muito bem construído e delineado pelo currículo da escola. Currículo, este, que não pode e nem deve ser entendido simplesmente como "grades" disciplinares que organizam conteúdos em um cronograma semestral, mas como um produto cultural construído pela luta da escola na atribuição de seus próprios significados e simbologias (LOPES; MACEDO, 2011).

Considerando o currículo na construção dos significados na escola, destacamos a importância das estratégias e dos recursos didáticos a serem utilizados para se atingir esse objetivo. No nosso caso, sob o referencial piagetiano, destacamos que tais estratégias podem retirar os estudantes da famosa "zona de conforto" em que, geralmente, eles se encontram, podendo desequilibrá-los, provocando-os a saírem de suas condições de passividade e agirem sobre os objetos de conhecimento, em busca da organização e adaptação que os levem a novas reequilibrações, o que resultará no processo de aprendizagem.

Dentre as várias estratégias pedagógicas possíveis, defendemos a utilização dos jogos educativos formalizados, sobretudo, os jogos pedagógicos como parte de um conjunto de situações estratégicas que serão propostas para o processo de ensino e aprendizagem. Sobre os jogos educativos, Soares (2013, p. 45) nos aponta que eles buscam "[...] aproximar o caráter lúdico existente no jogo à possibilidade de se aprimorar o desenvolvimento cognitivo". Logo, ao considerarmos que o jogo pedagógico objetiva desenvolver habilidades cognitivas, é preciso pensar naquilo que deve ser considerado como importante no momento da sua elaboração. E, justamente por isso, apresentamos a nossa proposta.

Ressaltamos que, para nós, o jogo pedagógico deve ser visto como um sistema projetado para possibilitar experiências pedagógicas, no entanto, deverá ser entendido como parte de um sistema maior que é o processo educativo formalizado. Ao pensarmos assim, destacamos que é preciso ter a clareza de que a presença/ausência dos jogos pedagógicos nas salas de aula não pode ser responsabilizada pelos fracassos no processo de ensino e aprendizagem escolar. O jogo pedagógico não deve ser visto como a panaceia responsável por buscar o êxito de todo o processo. Dito isso, vamos às características do esquema Educação Formal!

Ao falarmos em um jogo com o propósito pedagógico, é importante conhecer quais elementos constitutivos este jogo deve apresentar para afirmarmos que ele pode estar em uma sala de aula, ou seja, que se trata de uma estratégia pedagógica formal. Para fins de melhor entendimento do que estamos propondo, elaboramos um diagrama conceitual que busca apresentar, de modo relacionado, as principais características do esquema primário Educação Formal (Figura 2). 
Figura 2: Diagrama sobre o esquema primário Educação Formal.

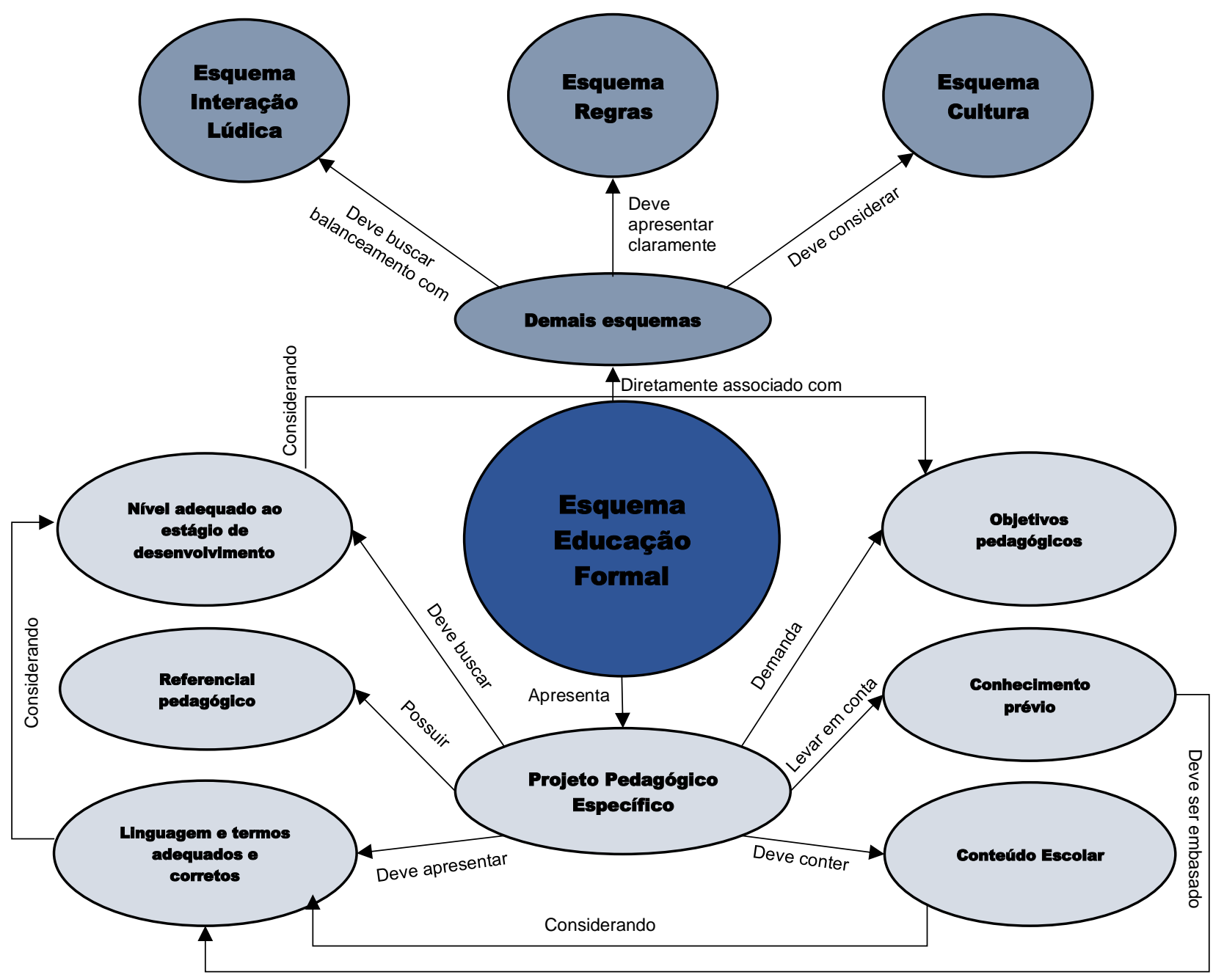

Fonte: elaborado pelos autores.

Ao se buscar construir um jogo pedagógico é preciso considerar que, de modo interdependente, deverá ocorrer a associação do esquema Educação Formal com os demais esquemas primários: Regras, Interação Lúdica e Cultura, pois o jogo não poderá deixar de manter as suas características básicas, ainda que com objetivos pedagógicos pretendidos. Ou seja, o sistema deverá ser projetado considerando as interações construtivas e pedagógicas que acontecerão no espaço de possibilidades propiciado pelas regras, pelo "círculo mágico" e pelos elementos culturais que fizerem parte do jogo.

A associação do esquema Educação Formal com o esquema Interação Lúdica, nos leva a considerar a necessidade de o jogo pedagógico preservar o caráter lúdico, intrínseco ao jogo, e a ele ser acrescido o caráter pedagógico. Soares (2013) afirma que um jogo com propósitos educativos deve ter muito bem balanceado o caráter didático e o caráter lúdico. Destacamos que o resultado desse balanceamento, entre as experiências de interação lúdica dos jogadores com o conhecimento específico, é que resultará no processo educativo. Para isso, entendemos que é preciso um planejamento cuidadoso dos tipos de interações lúdicas que possam possibilitar o propósito pedagógico. Vale destacar, também, que ainda que seja um jogo pedagógico, os jogadores devem sentir vontade de jogar pelo simples prazer de estarem jogando.

No que se refere à natureza das interações, o planejamento do jogo deve ser feito com muito conhecimento e cuidado para que ele cumpra com o objetivo pedagógico e, ao mesmo tempo, seja divertido e prazeroso. Neste caso, o conhecimento necessário a que nos referimos está relacionado com aquele do campo teórico do jogo, que subsidiará a elaboração do jogo seguindo os critérios necessários para que ele possibilite a interação lúdica de diferentes modos, buscando contemplar todos os envolvidos, 
sendo, principalmente, os jogadores e, também, o mestre, narrador, organizador ou dinamizador do jogo, quando existir.

Outra associação imprescindível de consideração é o esquema Educação Formal com o esquema Regras, uma vez que os jogos pedagógicos, no geral, são jogos regrados. Em defesa das regras, Soares $(2013$, p. 47) nos afirma que "[...] para uma perfeita relação entre o aprendiz e o jogo, faz-se necessária a presença de regras, explícitas ou não [...]". O autor destaca ainda que "[...] para um jogo funcionar adequadamente em sala de aula, faz-se necessária uma boa regra e que ela seja extremamente clara. Muitos insucessos em sala de aula não são causados pelo jogo, mas pela má explicação e explicitação das regras" (SOARES, 2013, p. 42-43).

As regras explícitas precisam ser claras, apresentarem linguagem adequada e amplamente esclarecedores de como cada participante deve jogar. Além disso, dependendo do tipo de jogo, as regras precisam destacar a importância de serem seguidas para que o jogo não tome outros caminhos durante a sua realização. Outro ponto a ser considerado sobre as regras é que elas são responsáveis pela manutenção dos jogadores no jogo, mantendo o "círculo mágico" em ação, portanto, isso também precisa ser considerado na criação de um jogo pedagógico.

Por fim, sobre a interação entre os esquemas no processo criativo, o esquema Educação Formal deve estar associado diretamente ao esquema Cultura. Sobre este esquema, ele só existe porque o ser humano é um ser social capaz de aprender e transmitir o que aprendeu para as próximas gerações, sendo o jogo entendido como uma prática social transmitida ao longo do tempo. Deste modo, ao pensarmos na associação entre os esquemas, entendemos que ao se buscar ensinar determinado conteúdo com a utilização de jogos, temos tanto o conteúdo, quanto o jogo em si, imbricados em uma cultura. É justamente essa imbricação que nos permite contextualizar o jogo pedagógico em um processo histórico educacional.

Outro aspecto importante dessa associação entre os dois esquemas conceituais está no fato das possibilidades de transformação e superação que o esquema Cultura apresenta. Dependendo dos objetivos pedagógicos pretendidos pelo jogo, alguns aspectos da cultura poderão estar mais ou menos presentes no jogo. Por exemplo, um jogo pedagógico que objetiva trabalhar com determinados assuntos da Genética Humana, pode abordar sobre preconceitos ainda muito presentes na cultura atual, como o racismo.

Concomitante a estas associações entre os esquemas primários, propomos que o esquema Educação Formal fundamente a elaboração do jogo pedagógico a partir de suas características peculiares, que estamos chamando de Projeto Pedagógico Específico. Nele, organizamos as características gerais, os sub-esquemas, que seguem:

- Objetivos pedagógicos - um jogo pedagógico deve ter objetivos pedagógicos. Com isso, precisamos nos atentar para a necessidade de um planejamento criterioso de tais objetivos. Alguns questionamentos deverão ser uma prática comum no processo inicial de elaboração do jogo, dentre eles, destacamos: será um jogo para trabalhar o ensino de determinado conteúdo (conceitos científicos)? A memorização? O reforço? A avaliação da aprendizagem? A quem será destinado o jogo? Para qual nível da Educação? Qual será a participação do(a) professor(a)?

Por exemplo, se pretendemos trabalhar com o ensino de conceitos das Ciências Naturais, precisamos considerar a necessidade da escolarização de tais conceitos para o contexto do jogo. Essa escolarização do conteúdo deve levar em consideração aspectos peculiares que dizem respeito ao "o quê" e "como" se pretende ensinar. Na escolarização do conteúdo há uma transposição do conhecimento de modo que ele possa ser ensinado por meio do jogo. Para que este conhecimento seja transposto de maneira adequada, é necessário que os elaboradores tenham a exata compreensão de que há uma diferença entre o conhecimento científico produzido pelos cientistas, o conhecimento científico transposto para o Ensino Superior (ofertado nas disciplinas de graduação) e o conhecimento científico transposto para a Educação Básica (ofertado nas disciplinas escolares do Ensino Fundamental e Médio), pois isso evitará uma maior "deformação" do conhecimento, adequando-o ao público em questão.

Para o conteúdo ser ensinado, o jogo pedagógico deve apresentar um enredo e/ou uma dinâmica de interação que possibilite isto. É importante esclarecermos que há de considerar-se o propósito pedagógico que o jogo irá objetivar, como ensinar conceitos novos ou apenas fixar e memorizar conceitos que já foram trabalhados anteriormente. O roteiro do jogo, bem como a sua 
dinâmica, devem ser elaborados sempre levando em consideração os objetivos pedagógicos que se pretendem conquistar, afinal, o caráter pedagógico é o que justifica pensarmos em um jogo pedagógico.

Ao pensarmos no caráter pedagógico a partir de um jogo, é importante observar que o jogo traz, intrinsecamente, uma característica muito significante para o processo de ensino e aprendizagem, que é a capacidade de despertar a curiosidade e o interesse. Soares (2013) destaca a vantagem de se trabalhar com o jogo pedagógico. Para o autor o jogo é intrinsecamente interessante ao estudante, despertando o desejo pelo ato de jogar. Consequentemente, estando o estudante interessado pelo jogo, este interesse poderá migrar para o conteúdo presente no jogo, o que o torna vantajoso no processo de aprendizagem.

Além desse interesse intrínseco ao jogo, Messeder-Neto (2016, p. 174) aponta que na escola "[...] o jogo é uma forma de ajudar o professor a pegar o aluno pela mão e trazê-lo para onde ele quer que o aluno chegue no processo educativo". Nosso pensamento coaduna com o do autor, no entanto, ressaltamos a importância de que os objetivos pedagógicos do jogo estejam muito claros. Afirmamos, portanto, que o ato de criação de um jogo pedagógico deve começar como qualquer outro ato pedagógico na escola, pelos objetivos pedagógicos que se pretendem atingir.

- Conhecimento prévio - entendemos que este sub-esquema está diretamente associado com os objetivos pedagógicos, mas não necessariamente os precedem. Por exemplo, se pretender ensinar determinados conceitos científicos com um jogo, este será o objetivo e, a partir dá, deverá investigar o conhecimento prévio dos estudantes em relação aos conceitos.

Considerando o processo educativo como uma adaptação do sujeito à sociedade, por intermédio dos inúmeros processos de assimilação e acomodação a que ele se submete, é importante compreendermos como os esquemas cognitivos do indivíduo se apresentam e estão organizados para determinado tipo de conhecimento. A este modo de apresentação e organização dos esquemas do sujeito, específicos para determinado assunto, estamos chamando de conhecimento prévio. Conhecimento este, independente das denominações que receba, tem recebido bastante atenção nas últimas décadas, em pesquisas voltadas aos processos de ensino e aprendizagem das Ciências Naturais, como podemos verificar em Carvalho (1992), Delizoicov, Angotti e Pernambuco (2002), Vasconcelos, Praia e Almeida (2003), Cachapuz et al. (2005) e Silva e Soares (2013).

Buscar conhecer como as estruturas cognitivas do sujeito se encontram organizadas para se relacionarem com os objetos de conhecimento, darão subsídios que contribuirão com o processo criativo do jogo pedagógico, relacionando com os objetivos pretendidos. O levantamento do conhecimento prévio dos estudantes pode permitir ao criador do jogo pedagógico pensar em situações interativas que promovam desequilíbrios a partir do que os estudantes apresentam esquematizados em relação a determinado conteúdo.

Além disso, cabe destacar que a responsabilidade da educação formal praticada nas escolas é com o conhecimento científico, ainda que ela não pretenda, e nem deva, desprezar os outros tipos de conhecimentos, como o popular. No entanto, ao verificar o conhecimento prévio dos estudantes, é possível visualizar quais tipos de conhecimentos estão prevalecendo no processo de construção dos seus significados conceituais. Deste modo, é possível propor atividades, como o jogo pedagógico, que possam intervir diretamente na (re)construção dos esquemas, com ênfase no conhecimento científico.

Assim, defendemos que o jogo pedagógico, construído a partir dos conhecimentos prévios dos estudantes, poderá se apresentar mais familiar a eles e facilitar no processo de construção do conhecimento e, consequente, aprendizagem.

- Conteúdo escolar - a partir do momento que estamos tratando de um jogo com propósitos pedagógicos, no contexto da Educação Formal, temos que ter claro quais conteúdos escolares estarão presentes no jogo. Ora, se o jogo está sendo pensado com o propósito de promover a aprendizagem, é crucial que se tenha a clareza do que se espera que seja aprendido.

O jogo pedagógico deverá ter algum conteúdo escolar a ser aprendido, caso contrário, ele deixa de ser pedagógico. A esse respeito, Messeder-Neto (2016, p. 173-174) aponta que "[...] o jogo precisa ajudar o aluno na apropriação do conhecimento científico, pois só assim ele estará contribuindo para o desenvolvimento psíquico e exigindo do aluno mais do que ele pode no momento, avançando sempre para a atividade de estudo". No entanto, o autor destaca que para que isso aconteça é preciso 
que o jogo não esteja esvaziado de conteúdo. Por isso, o planejamento do jogo deverá estar atento em relação às escolhas que serão feitas, sob o risco de não conseguirmos construir um jogo pedagógico, mas apenas um jogo recreativo.

A escolha do conteúdo escolar a ser contemplado pelo jogo é um processo que demanda bastante cuidado e atenção, devendo ser levado em consideração o domínio de tal conhecimento por parte do criador do jogo pedagógico. O ideal é que o conhecimento esteja associado diretamente com o currículo que fundamenta a unidade escolar. Além disso, que este conteúdo, quando conceitual, tenha o compromisso com o conhecimento científico e que não seja transposto de maneira errada, aproximandose muito mais de um conhecimento popular do que científico, devido às deformações sofridas.

Outro aspecto a ser considerado a respeito do conteúdo é que, dependendo da sua natureza, será preciso que o jogo o apresente em uma sequência lógica, para que possa fazer sentido no processo de compreensão. Como acontece com qualquer outra estratégia pedagógica, alguns conteúdos precisam seguir uma sequência para se tornarem compreensíveis e, sobretudo, aprendidos. Pois, para se compreender determinado conceito, haverá a necessidade de que se tenha organizado esquemas conceituais anteriores.

- Nível adequado ao estágio de desenvolvimento - este sub-esquema também está diretamente associado aos objetivos pedagógicos do jogo, pois ao pensarmos nos objetivos, devemos ter claro o perfil dos jogadores ao qual o jogo será destinado. Já dissemos que o jogo pedagógico deve ser capaz de envolver os estudantes em seu enredo, fazendo com que se abstraiam da vida real ao imergirem na situação imaginária que será proporcionada. Para isso, é importante que o jogo esteja adequado ao nível de desenvolvimento dos jogadores, considerando as habilidades e capacidades cognitivas apresentadas por eles. Afinal, não é por acaso que os jogos comerciais disponíveis no mercado trazem a idade recomendada para os jogadores.

Considerando a especificidade do referencial teórico adotado, no nosso caso Piaget, é preciso levar em consideração o desenvolvimento do sujeito. Para Piaget (1982) a aprendizagem se dá a partir do desenvolvimento, portanto, se o sujeito ainda não desenvolveu o suficiente, não terá capacidades cognitivas de compreensão e de aprendizagem de determinados conteúdos, como é o caso de conceitos complexos que demandam a abstração. Nesse caso, não adianta buscar a compreensão de determinados conceitos por parte dos estudantes; o jogo é que deverá ser adequado aos jogadores e não o contrário! Um jogo que apresentar um conteúdo muito além do possível de ser compreendido, poderá levar ao desinteresse, se tornar cansativo, complicado e possivelmente chato, o que poderá romper com o "círculo mágico".

Nessa busca pela adequação ao estágio de desenvolvimento, o tipo de jogo também deverá ser considerado porque, a depender do nível de complexidade, os jogadores não conseguirão jogar, ou, mesmo jogando não conseguirão atingir os objetivos pedagógicos a que o jogo propõe. Por exemplo, não adianta querer jogar xadrez com uma criança de 2 anos de idade, muito menos querer ensinar um conteúdo escolar a ela por meio da dinâmica do jogo de xadrez.

Uma vez considerando o estágio de desenvolvimento, é preciso considerar, também, o tempo que o jogo terá. Dependendo da idade dos jogadores a atenção será perdida em pouco tempo. O tempo poderá influenciar nos tipos de interações lúdicas que serão alcançadas pelo jogo. O cansaço pode levar ao desinteresse, que por sua vez, poderá levar ao rompimento do "círculo mágico". No entanto, não estamos dizendo que os jogos pedagógicos devam ser rápidos, apenas estamos afirmando que o tempo de jogo deve ser pensado de acordo com o estágio de desenvolvimento dos jogadores. Afinal, mesmo alguns jogos sendo demorados, eles podem ser dinâmicos e não cansativos.

- Linguagem e termos adequados - algo que está diretamente associado aos conteúdos propostos no jogo pedagógico, é o cuidado com a linguagem e os termos a serem utilizados. Até poderíamos ter realizado esta discussão dentro do sub-esquema "Conteúdo escolar", no entanto, não a fizemos porque não estamos considerando aqui apenas o cuidado com o conteúdo, mas, também, com o jogo em geral.

A linguagem adequada é muito importante ao considerarmos a escolarização do conteúdo no jogo; se ela não for compreensível, dado os diferentes tipos de letramentos dos estudantes, o conteúdo não será aprendido. No entanto, a adequação da linguagem não quer dizer que ela deva ser simplificada a ponto de se assemelhar com o aspecto coloquial, cuja intenção é aproximar-se dos estudantes, mas que 
deva considerar o contexto deles e apresentar um vocabulário que seja compatível aos seus níveis de entendimento. Messeder-Neto (2016, p. 177) ressalta que "é necessário que o conceito que será aprendido, discutido ou retomado esteja claro para o estudante durante todo o jogo, caso contrário ele não ocupará lugar central na atividade realizada".

O cuidado na escolha das terminologias a serem utilizadas também é muito importante. Em determinadas áreas, como por exemplo, na Biologia, o conhecimento científico é construído com a utilização de muitas terminologias, sendo várias delas de difícil compreensão. Deste modo, na elaboração de um jogo pedagógico é importante considerar se há a necessidade de utilizar determinadas terminologias ou não. Refletir sobre os reais significados que poderão ser atribuídos ao termo no decorrer do jogo é um exercício que nós recomendamos que seja feito durante o processo criativo.

É importante destacar que, quanto mais compreensível o jogo pedagógico apresentar o conteúdo escolar aos estudantes, teremos maiores chances de ocorrer a aprendizagem sem as assimilações deformantes. Considerando que as assimilações deformantes podem contribuir para a construção de esquemas que se consolidarão em concepções equivocadas, ou erros conceituais.

Para além do cuidado com a linguagem e os termos em relação ao conteúdo escolar a serem trabalhados no jogo, destacamos a necessidade do cuidado que também deve acontecer em relação a utilização de uma linguagem e termos apropriados para o ambiente escolar. Afinal, não se trata de um jogo elaborado para momentos de lazer em espaços informais. No espaço escolar se deve prezar por uma boa conduta e evitar a utilização de determinados termos, como palavrões. A não ser que seja um dos propósitos do jogo apresentar uma reflexão qualquer sobre alguns aspectos culturais contemporâneos, como no caso de entendermos o jogo como um elemento de transformação da cultura.

Outro aspecto importante da preocupação com a linguagem e os termos, está relacionado com a utilização de termos complicados na elaboração das regras. Isto deve ser evitado, pois vale lembrar que as regras precisam ser completamente compreensíveis para o bom andamento do jogo. Se determinados termos estiverem distantes do vocabulário dos jogadores, estes enfrentarão dificuldades para entender a mecânica de funcionamento do jogo.

- Referencial pedagógico - por fim, como característica pedagógica específica do esquema primário Educação Formal, precisamos pensar nos referenciais que embasarão o planejamento do processo de ensino e aprendizagem. Propomos que o jogo pedagógico deva ser pensado a partir de referenciais que se direcionem ao encontro daquilo que se pretenda atingir enquanto atividade educacional formalizada. Algo que deveria ser natural, mas, infelizmente não é.

Soares $(2018$, p. 235) aponta que as propostas de jogo educativo formalizado que se baseiam em algum referencial da aprendizagem ainda são muito incipientes. Para ele "[...] é importante salientar que, de fato, há poucos trabalhos que fazem uma relação direta do jogo com alguma teoria de aprendizagem - principalmente no que se refere à teoria piagetiana”.

Rezende (2017) verificou que os jogos utilizados no ensino de Química, têm utilizado referenciais teóricos/epistemológicos como Piaget e Vygotsky, mas o modo como os referenciais têm sido apropriados pelos jogos demonstra a pouca preocupação dos autores com as teorias de aprendizagem. Em muitos casos, os jogos acabam perdendo os aspectos pedagógicos.

Qualquer processo de educação formal precisa ser pensado a partir de referenciais teóricos específicos que discutam sobre os processos de aprendizagem. Independente do referencial teórico adotado, é preciso que o planejamento leve em conta questionamentos do tipo: como ocorre a aprendizagem? Qual a participação do estudante (sujeito)? Qual a participação do professor? Onde o jogo pedagógico se insere no processo de aprendizagem? Como o jogo pedagógico pode contribuir para a aprendizagem? Como ocorrerá a relação do sujeito com o objeto de aprendizagem por meio do jogo pedagógico?

Estes e outros questionamentos devem ser respondidos com o auxílio de um referencial teórico consistente, que permita ao responsável pela criação do jogo buscar o melhor projeto a ser desenvolvido para se atingir os objetivos pretendidos. Em nosso trabalho, nos respaldamos em Piaget como o referencial que nos forneceu todas as respostas necessárias para pensarmos o jogo pedagógico, considerando os elementos conceituais do esquema primário Educação Formal. No entanto, destacamos que outros referenciais podem ser adotados, como Vygotsky, Wallon (1879-1962) e Gagné (1916-2002), dependendo dos posicionamentos teóricos de quem está elaborando o jogo. 
Com isso, encerramos a apresentação do esquema primário Educação Formal, considerando-o como um esquema conceitual que poderá auxiliar no planejamento, elaboração e avaliação de jogos pedagógicos. Esperamos que ele possa ser útil para a elaboração de jogos pedagógicos de sucesso. Ressaltamos, contudo, termos a clareza de que mesmo que o jogo pedagógico tenha uma ótima qualidade, será a maneira como utilizado em sala de aula que determinará o seu sucesso. Neste caso, preferimos manter os sujeitos da relação, estudantes e professores, em papel de destaque.

\section{CONSIDERAÇÕES FINAIS}

Como professores formadores na área das Ciências Naturais, apresentamos nossa proposta considerando as possibilidades de utilização do jogo pedagógico para trabalhar no ensino e na aprendizagem de conteúdos específicos dessa área. No entanto, não descartamos a possibilidade da utilização dos jogos pedagógicos para o ensino e a aprendizagem de conteúdos relativos a qualquer área presente no contexto da Educação Formal, desde a Educação Infantil ao Ensino Superior.

Esperamos que este trabalho possa contribuir para a ampliação da discussão teórica sobre jogos educativos formalizados, no sentido de refletirmos sobre a necessidade de se avançar nos aspectos teóricos relacionados à essa produção, dando mais densidade teórica ao jogo, alçando-o à condição de estratégia pedagógica importante para a sala de aula.

\section{REFERÊNCIAS}

ANJOS, José Ayron Lira; GUIMARÃES, Ricardo Lima. Potenciais contribuições do jogo didático na perspectiva da teoria de aprendizagem de Gagné. In: CLEOPHAS, M. G.; SOARES, M. H.F.B. (Orgs). Didatização Lúdica no ensino de Química/Ciências: teorias de aprendizagem e outras interfaces. São Paulo: Editora Livraria da Física, 2018. p. 139-149.

ARAÚJO, Everaldo dos Santos.; SANTOS, Bianca Martins. JOGO DAS GRANDEZAS: UM RECURSO PARA O ENSINO DE FÍSICA. Revista do Professor de Física, [S. 1.], v. 2, n. 2, 2018. DOI: 10.26512/rpf.v2i2.12079. Disponível em: https://periodicos.unb.br/index.php/rpf/article/view/12079. Acesso em: 3 março. 2020.

BODLEY, John H. Cultural Anthropology: Tribes, States, and the Global System. New York: McGraw-Hill Higher Education, 1994.

BRASIL. Lei n⿳ 9.394/96, de Diretrizes e Bases da Educação Nacional. Brasília: Subsecretaria de Edições Técnicas, Diário Oficial da União, 23/12/ 96, Brasília - DF, 1996.

BROUGÈRE, Gilles. Jogo e educação. Trad. Patrícia C. Ramos. Porto Alegre: Artes Médicas, 1998.

. Lúdico e educação: novas perspectivas. Linhas Críticas, [S. 1.], v. 8, n. 14, p. 5-20, 2002. DOI: $\quad$ 10.26512/lc.v8i14.2985. Disponível em: https://periodicos.unb.br/index.php/linhascriticas/article/view/2985. Acesso em: 5 março. 2020.

CACHAPUZ, Antônio; GIL-PEREZ, Daniel; CARVALHO, Anna Maria; PRAIA, João; VILCHES, Amparo. (Orgs.). A necessária renovação do ensino das Ciências. São Paulo: Cortez, 2005.

CAILLOIS, Roger. Os jogos e os homens: a máscara e a vertigem. Trad. por Maria Ferreira. Petrópolis, RJ: Editora Vozes, 2017.

CARVAlHO, Anna Maria Pessoa. Construção do conhecimento e ensino de Ciências. Em Aberto, Brasília - DF, v. 11, n. 9, jul./set., 1992. DOI: http://dx.doi.org/10.24109/21766673.emaberto.11i55.1852. Disponível http://rbepold.inep.gov.br/index.php/emaberto/article/view/1852. Acesso em: 5 março. 2020. 
CUNHA, Marcia Borin. Jogos no Ensino de Química: Considerações Teóricas para sua Utilização em Sala de Aula. Química Nova na Escola, São Paulo - SP: SBQ, v.34, n.2, p. 92-98, maio, 2012. Disponível em: http://qnesc.sbq.org.br/online/qnesc34_2/07-PE-53-11.pdf. Acesso em: 3 março. 2020.

CHATEAU, Jean. O jogo e a criança. Trad. por Guido de Almeida, São Paulo: Summus, 1987.

CLEOPHAS, Maria das Graças; CAVALCANTI, Eduardo Luiz Dias; SOARES, Márlon Herbert Flora Barbosa. Afinal de contas, é jogo educativo, didático ou pedagógico no ensino de Química/Ciências? Colocando os pingos nos "is". In: CLEOPHAS, Maria das Graças; SOARES, Márlon Herbert Flora Barbosa (Orgs). Didatização Lúdica no ensino de Química/Ciências: teorias de aprendizagem e outras interfaces. São Paulo: Editora Livraria da Física, 2018. p. 33-43.

DELIZOICOV, Demétrio; ANGOTTT, José André; PERNAMBUCO, Marta Maria. Ensino de Ciências: fundamentos e métodos. São Paulo: Cortez, 2002.

DUARTE, Thiago Sousa; BATISTA, Daniele Mesquita; JESUS, Andressa Kelly Silva; MEDEIROS, Maria Helena; OKADA, Yukari; IKETANI, Gabriel. Roleta da Evolução: uma ferramenta didática para o ensino de Biologia no Ensino Médio. In: ENCONTRO NACIONAL DE PESQUISA EM EDUCAÇÃO EM CIÊNCIAS, 11., Florianópolis, 2017. Anais do XI Encontro Nacional de Pesquisa em Educação em Ciências - XI ENPEC - Universidade Federal de Santa Catarina, Florianópolis, SC, 2017.

GALVÃO, Mayra de Freitas; BASTOS, Rafael Wesley; MOREIRA, Fabiana Freitas; RODRIGUES, Adriana de Castro; YOTOKO, Karla Suemy Clemente. Jogo da Evolução. Genética na Escola. Sociedade Brasileira de Genética, v. 7, n. 2, p. 66-73, 2012. Disponível em: https:/ /7ced070d-0e5f-43ae9b1c-aef006b093c9.filesusr.com/ugd/b703be_293e65d230354d2ba43b50ae10f41336.pdf. Acesso em: 10 março. 2020.

HOUAISS, Antônio. Dicionário Eletrônico Houaiss da Língua Portuguesa. Rio de Janeiro: Objetiva, 2009. E-book.

HUIZINGA, Johan. Homo ludens: o jogo como elemento da cultura. Trad. por João Paulo Monteiro, $7^{\mathrm{a}}$ ed., São Paulo: Perspectiva, 2012.

KISHIMOTO, Tizuko Morchida. O jogo e a Educação infantil. In: KISHIMOTO, Tizuko Morchida (org.) Jogo, brinquedo, brincadeira e educação. 14ª ed., São Paulo: Cortez, 2011. p. 15-48.

LOCATELLI, Solange Wagner. Jogo e ensino de Química: uma relação metacognitiva no processo de aprendizagem. In: CLEOPHAS, Maria das Graças; SOARES, Márlon Herbert Flora Barbosa (Orgs). Didatização Lúdica no ensino de Química/Ciências: teorias de aprendizagem e outras interfaces. São Paulo: Editora Livraria da Física, 2018. p. 153-165.

LOPES, Alice Casimiro; MACEDO, Elizabeth. Teorias de Currículo. São Paulo: Cortez, 2011.

MESSEDER-NETO, Hélio da Silva. O lúdico no ensino de Química na perspectiva históricocultural: além do espetáculo, além da aparência. Curitiba: Editora Prismas, 2016.

MIRANDA, Ana Flávia Souza. Jogos pedagógicos no processo de ensino e aprendizagem em Química na modalidade Educação de Jovens e Adultos. 2015. Dissertação (Mestrado em Educação em Ciências). Universidade Federal de Goiás - UFG, Goiânia - GO, 2015. 
PIAGET, Jean. A formação do símbolo na criança: imitação, jogo e sonho, imagem e representação. Trad. por Álvaro Cabral e Christiano Monteiro Oiticica. $3^{a}$ ed., Rio de Janeiro: Zahar Editores, 1978.

. Epistemologia Genética. In: EVANS, Richard I. Jean Piaget: o homem e suas ideias. Trad. por Angela Oiticica. Rio de Janeiro: Forense-Universitária, 1980.

Psicologia e Pedagogia. Trad. por Dirceu Accioly Lindoso e Rosa Maria Ribeiro da Silva. Rio de Janeiro: Forense Universitária, 1982.

Janeiro: LTC, 1987.

O nascimento da inteligência na criança. Trad. por Álvaro Cabral. $4^{a}$ ed., Rio de

REZENDE, Felipe Augusto de Mello. Jogos no ensino de Química: um estudo sobre a presença/ausência de teorias de ensino e aprendizagem à luz do V epistemológico de Gowin. 2017. Dissertação (Mestrado em Educação em Ciências e Matemática) - Universidade Federal de Goiás - UFG, Goiânia - GO, 2017.

REZENDE, Felipe Augusto de Mello; CARVALHO, Christina V. M.; GONTIJO, Lucas C.; SOARES, Márlon Herbert Flora Barbosa. RaioQuiz: Discussão de um conceito de propriedade periódica por meio de um jogo educativo. Química Nova na Escola, vol. 41, n. 3, p. 248-258, 2019. DOI: http://dx.doi.org/10.21577/0104-8899.20160149. Disponível em: http://qnesc.sbq.org.br/online/qnesc41_3/07-RSA-19-18.pdf. Acesso em: 15 janeiro. 2020.

SALEN, Katie; ZIMMERMAN, Eric. Rules of play: game design fundamentals. Cambridge, MA: The MIT Press, 2004.

Regras do jogo: fundamentos do design de jogos. Principais conceitos, vol. 1. Trad. por Edson Furmankiewicz. São Paulo: Blucher, 2012a.

Regras do jogo: fundamentos do design de jogos. Regras, vol. 2.

Trad. por Edson Furmankiewicz. São Paulo: Blucher, 2012b.

Regras do jogo: fundamentos do design de jogos. Interação Lúdica, vol. 3. Trad. por Edson Furmankiewicz. São Paulo: Blucher, 2012c.

Regras do jogo: fundamentos do design de jogos. Cultura, vol. 4.

Trad. por Edson Furmankiewicz. São Paulo: Blucher, 2012d.

SILVA, Vitor de Almeida; SOARES, Márlon Herbert Flora Barbosa. Conhecimento Prévio, Caráter Histórico e Conceitos Científicos. Química Nova na Escola. v. 35, n 3., p. 209-219, 2013. Disponível em: http://qnesc.sbq.org.br/online/qnesc35_3/10-PE-04-12.pdf. Acesso em: 10 janeiro. 2020.

SOARES, Márlon Herbert Flora Barbosa. O lúdico em Química: jogos e atividades aplicados ao Ensino de Química. 2004. Tese (Doutorado em Ciências) - Instituto de Química, Universidade Federal de São Carlos, São Carlos - SP, 2004.

Goiânia: Kelps, 2013.

Jogos e Atividades Lúdicas para o ensino de Química.

. O jogo e suas possíveis relações com a Epistemologia Genética de Jean Piaget: em um tabuleiro de xadrez. In: CLEOPHAS, Maria das Graças; SOARES, Márlon Flora Barbosa Soares. (Orgs). Didatização Lúdica no ensino de Química/Ciências: teorias de aprendizagem e outras interfaces. São Paulo: Editora Livraria da Física, 2018. p. 235-248. 
VASCONCELOS, Clara; PRAIA, João Félix; ALMEIDA, Leandro S. Teorias de aprendizagem e o ensino/aprendizagem das ciências: da instrução à aprendizagem. Psicol. esc. educ., Campinas, v. 7, n. 1, p. 11-19, jun. 2003. Disponível em $<$ http://pepsic.bvsalud.org/scielo.php?script=sci_arttext\&pid=S141385572003000100002\&lng=pt\&nr $\mathrm{m}=$ iso $>$. Acesso em: 10 março. 2020.

Submetido: $28 / 08 / 2020$

Aprovado: $10 / 03 / 2021$ 